\title{
Identification of internal and external factors affecting the optimal implementation of government policies
}

\author{
Professor Dr. Sorush Niknamian \\ Board Member of Weston A Price Foundation, Washington Dc, USA \\ E-mail: so.niknamian@gmail.com
}

\begin{abstract}
The purpose of this study was to identify the internal and external factors associated with the implementation of the organization's policies. It was an applied-descriptive study conducted through a survey method using a questionnaire. For the purpose of this study, after reviewing the literature and theoretical foundations, we tried to identify the most important internal and external factors affecting optimal policy implementation. Therefore, seven factors and their indices were selected based on frequency and importance. In the form of seven hypotheses, the relationship between these factors and optimized policy implementation was evaluated. The statistical population included 120 employees of the Department of Natural Resources and Watershed Management of Khorasan Razavi province. The sample size was calculated using the Morgan formula to be 92 people. Regarding the fact that the policy implementation had an abnormal distribution, the nonparametric single t-test was used to test the hypotheses. The results indicated a positive and significant relationship between all internal and external organizational factors identified by optimal policy implementation in the organization.
\end{abstract}

\section{Keywords:}

Intra-organizational factors, extra-organizational factors, optimal policy implementation

\section{Introduction}

General policies is a set of relatively steady and purposeful actions of the state to solve the problems or public concerns of society (Anderson, 2011, 7). Since the general policy was introduced after the Second World War, the central role of government in the new world is public policy making (Bozorgi, 2013, 12). Generally, policy has three stages: compilation, implementation, and evaluation. After issuing a general policy, deciding some plan for solving and choosing a decision by the government, the implementation should be done. This stage of the linear cycle is executed, which can be defined as a process in which programs or scripts are operational (Mounirian and Golshan, 2001, 8). Despite the growing importance of the general rule in the effective and efficient governance of states, what we are faced with in practice is that governments generally do not succeed in implementing a general policy. One of the most important issues facing many countries today, including developed and developing countries, is unsuccessful implementation of general policies (Hajipur et al., 2015, 4).

Until recently, even policy analysts have tended to underestimate the performance because they believed that everything that became law would be enforced. Analysts have traditionally focused on policy-making institutions such as the president, parliament, and perhaps the courts, and have 
examined the policy from the moment they are formed in the political system until the moment of admission (David Truman, 1971, 8). Many efforts have also been made by various theorists to provide a model for successful policy implementation, but the results from the implemented policies indicated that the proposed models did not have very favorable results. (Gilipur, 2003, 110).

The process of policy implementation takes place in an environment in which different actors are involved. At the same time, these actors interact with one another, and these interactions, due to political, economic, cultural, etc. differences affect the process of implementing the policy. Because of these political, economic and cultural differences, the use of models presented by different theorists in all circumstances is not very appropriate. Therefore, in order to successfully implement the developed policies, it seems necessary to identify and consider relevant and effective factors that are appropriate to the specific conditions of the policy and its field of operation (Table 1).

As the table shows, scholars and experts in the field of policy making, considered different factors in the implementation and failure to successfully and efficiently implement the policies. Therefore, in the present research, the fundamental question is that:

"Is there a relationship between the internal and external factors with the best way to implement the policies?"

First, you must understand the two variables (internal and external factors, and policy execution). Accordingly, implementation of the policy is considered a dependent variable and the role of the independent variable is considered on it.

The internal and external factors that play the role of independent variables include all internal and external factors such as the commitment of the executive, bureaucracy, how to formulate the policy, the specialty of the executive, the target community, the guarantee of implementation, the implementation tool and job satisfaction of executor.

Exploratory studies, summarized in Table 1, found seven factors that appeared most important. These seven factors do not merely cover all internal and external factors of the organization, and therefore, seven factors were chosen to maintain the limitation of the subject in order to achieve valid results. Also, these seven factors were recognized as more important and more complete factors.

Therefore, the research hypotheses were as follow:

1. The executor commitment is related to the implementation of the policies of the Department of Natural Resources and Watershed Management in Khorasan Razavi province.

2. The "bureaucracy" factor is related to the implementation of the policies of the Department of Natural Resources and Watershed Management of Khorasan Razavi province.

3. "How to formulate the policies" is related to the implementation of the policies of the Department of Natural Resources and Watershed Management in Khorasan Razavi province. 
4. The "expert's specialty" factor is related to the implementation of the policies of the Office of Natural Resources and Watershed Management of Khorasan Razavi province.

5. The "target community" is associated with the implementation of the policies of the Office of Natural Resources and Watershed Management of Khorasan Razavi province.

6. The "implementation guarantee" is related to the implementation of the policies of the Department of Natural Resources and Watershed Management of Khorasan Razavi province.

7. The "implementation tool" is related to the implementation of the policies of the Office of Natural Resources and Watershed Management of Khorasan Razavi province.

\section{Tools and Techniques}

Since the main objective of the research was to identify and explain the internal and external organizational factors affecting the optimal implementation of general policies, the present study was a combination of library and field studies and was a descriptive-correlative research which was conducted using a survey method. It can also be said that this research is a single-sectional research as it does not seek to investigate a phenomenon over time or in different sections. The steps followed in this study were based on the seven-step method of Sondelowsky and Barroso (2007), which include:

1. Proposing Research question;

2. Review of systematic literature;

3. Searching and selecting appropriate articles;

4. Exporting article information;

5. Analysis and synthesis of qualitative findings;

6. Quality control;

7. Delivering Findings.

In order to determine the coefficient of importance and priority of each of the discovered concepts, exploratory factor analysis and confirmatory factor analysis have been used.

The statistical population of this study was 120 staff of the Natural Resources and Watershed Management Department of Khorasan Razavi province. For determination of the required sample size, 92 people were seleted using Morgan formula.

In order to collect the required information, according to the literature and according to the opinion of the supervisor and also the modeling of reliable and standard samples, the researcher used a researcher-made questionnaire.

The researcher has done the following to determine the validity of this research.

A) Face validity: Taking the professors consent.

B) Determining the questionnaire validity. The KMO's was 0.449 and Bartelt test was 1921/991 and 0.0001 , respectively, indicating that the sample size is appropriate for fator analysis. It should be noted that these eight factors account for about $78 \%$ of the variance. 
Also, to assess the reliability of the questionnaire, the Cronbach's alpha method, which in most studies was based on reliability measurements, has been used. In the table below, the reliability of the questionnaire was calculated based on Cronbach's alpha coefficient (Table 2).

Given the suitability of the alpha coefficients, the internal validity (reliability) was confirmed.

Due to the fact that the implementation of the policies of the General Directorate of Natural Resources and Watershed of Khorasan Razavi Province had an abnormal distribution, the nonparametric single t-test was used to determine the significance of the of the sample.

\section{Results of data analysis}

1. The result of descriptive analyzes of data

2- Demographic characteristics of employees of the Natural Resources and Watershed Management Department of Khorasan Razavi

Gender: $82.6 \%$ male and $17.4 \%$ female.

Age: $8.8 \%$ between 21 and 30 years, $34.7 \%$ between 31 and 40 years, $46.7 \%$ between 41 and 50 years, and $10 \%$ over 50 years.

Educational degree: $10 \%$ diploma, 16.3 percent higher diploma, 46.7 percent BA, 27 percent MA and higher.

Job status: $42.4 \%$ official, $21.7 \%$ specific job, $20.6 \%$ corporate and $15.2 \%$ others.

Experience in the organization: $7.6 \%$ less than 5 years, $23.9 \%$ was between 5 to 10 years, $55.4 \%$ was between 11 to 15 years, $10 \%$ between 15 and 20 years, and 1/3\% over 20 years old.

2. The result of inferential data analysis

Normality assumption

Before determining the type of test used, especially in comparative tests, it is necessary to make sure that the variables are normal (Table 3 ).

The result is that the quality of the variables is recorded in the table and all were abnormal.

\section{Test of hypotheses}

Due to the fact that the variables related to the relationship between the factors related to the implementation of policies of the departments of the Natural Resources and Watershed Administration of Khorasan Razavi province had an abnormal distribution, we used a nonparametric test. Now, if we suppose that $M$ is the real median of the relationship between the factors associated with the implementation of the policies of the Office of Natural Resources and Watershed of Khorasan Razavi province, given that the variable of the relationship between the factors associated with the implementation of the departments of the Office of Natural Resources and Watersheds Khorasan Razavi province has values between 1 and 5, so we consider the values 
less than or equal to 3 as ineffective and more than 3 as effective, so we have to test the following assumptions:

: The relationship between the factors associated with the implementation of the policies of the Natural Resources and Watershed Administration of Khorasan Razavi province is not appropriate.

: The relationship between the factors related to the implementation of the policies of the General Directorate of Natural Resources and Watershed Management in Khorasan Razavi province is appropriate.

A summary of the $t$ test results is presented in Table 4.

Table 4. The results of t-test results on the relationship between factors associated with implementation of general policies

Hypothesis 1: The executor commitment is related to the implementation of general policies.

As can be seen from the results of the table, the mean of the relationship between the factor of "commitment of the executor" and the implementation of the policies of the Natural Resources and Watershed Management Office of Khorasan Razavi province was 4.19 with a standard deviation of 0.28 and a median of 5. Also, the significance level of the test was 0/0001; therefore, the null hypothesis is rejected.

This conclusion is in line with the results of Van Horn and Van Mitr's (1975), Eugene Bardej (1977), Warwick (1982), Hee Young Sook (1988), Discovery (2005), Mortazavi, Foruzandeh Dehkordi and Zareapour Nasiri (2011) and Zargham Boroujini (1393).

Second hypothesis: The "bureaucracy" factor is related to the implementation of general policies.

As it is seen in the results of the table, the mean of the bureaucracy's relationship with the implementation of the policies of the Department of Natural Resources and Watershed of Khorasan Razavi province was 4.5 with a standard deviation of 0.29 and a median of 4.5 . Also, the level of significance of the test was 0/0001, So, the null hypothesis is rejected.

This conclusion is in line wih the results of Van Horn and Van Mitr (1975), Rin and Robin Witz (1978), Richard Elmore (1980), Garcia Zamor (1980), Edwards (1980), Nakamura and Smallville (1980), and Zargham Boroujeni (1393).

Hypothesis 3: The "policy formulation" factor is related to the implementation of public policies.

As can be seen from the results of the table, the mean of the relationship between "how to formulate a policy" and implementing the policies of the Office of Natural Resources and Watershed of 
Khorasan Razavi province was 4.4 / 4 with a standard deviation of 0.38 and a median of 4.592 . Also, the level of significance of the test was 0/0001; therefore, The null hypothesis is rejected.

This conclusion is in line with the results of the research by Winter (1990), Callista (1995), Howell et Ramesh (1995), Nakamura and Smallville (1980), Fallan (1982), Aguanen (1991), Quind (1986), Grindel (2000), Samuel Stalli (2006), Sue Zhang and Rhine (2006) and Zargham Borujeni (1393).

Fourth hypothesis: The factor of "executor specialty" is related to the implementation of general policies.

As it is seen in the table, the mean of the relationship between the "executor specialty" and the implementation of the policies of the Office of Natural Resources and Watershed of Khorasan Razavi province was 4.36 with a standard deviation of 0.52 and a median of 4.25 . Also, the level of significance of the test was 0.0001 ; therefore, the null hypothesis is rejected.

This conclusion is in line with the results of the results of Van Horn and Van Mitter (1975), James Anderson (1982), Nakamura and Smallville (1980), Hee Young Suec (1988), Barry et al. (1998), Palmbo and Callista (1990) Hafiz Khalid (2001), Khouza (2003), Discourse (2005), Binard (2005), Lee, Laie and Fang (2006) and Zargham Borujeni (1393).

The fifth hypothesis: The "target community" factor is related to the implementation of general policies.

As can be seen in the results of the table, the mean of the relationship between the target community and the implementation of the policies of the Office of Natural Resources and Watershed of Khorasan Razavi province was 4.7 with a standard deviation of 0.45 and a median of 5 . Also, the level of significance of the test is $0 / 0001$; therefore, the null hypothesis is rejeceted.

This result is in line with the results of Van Horn and Van Mitr (1975), Nakamura and Smallville (1980), James Anderson (1982), Winterter (1990), Callista (1995), Howold and Ramesh (1995), Sabatyr and Mazmanian 1996), Howellt and Discovery (2005) and Brinard (2005).

The sixth hypothesis: The "implementation guarantee" factor is related to the implementation of general policies.

As seen in the results of the table, the mean of the relationship between the "guarantee of implementation" and the implementation of the policies of the Office of Natural Resources and Watershed of Khorasan Razavi province was 4.58 with a standard deviation of 0.36 and a median of 4.625. Also, the level of significance of the test was 0.0001 ; the null hypothesis is rejected.

This result is in line with the results of Rin and Robin Witz (1978), Callista (1995), Sabater and Mazmanian (1996), Howold and Ramesh (1995), Nakamura and Smallville (1980), Hee Young Suec (1988), Management Board The US government collaborates with the General Government Public Administration Unit (2002) and Samuel Stalli (2006).

Seventh hypothesis: The "tool" factor is related to the implementation of general guidelines. 
As seen in the results of the table, the mean of the relationship between the "implementation tool" and the implementation of the policies of the Office of Natural Resources and Watershed in Khorasan Razavi province was 4.97 with a standard deviation of 0.32 and a median of 4.667. Also, the significance level of the test was 0.0001 , therefore, the null hypothesis is rejected.

This result is in line with the results of research by Persman and Wildovsky (1973), Van Horne and Van Mitter (1975), Callista (1995), Fallan (1982), Hee Young Suec (1988), Papados Paul (1998), Palmbo and Callista 1990), Discourse (2005) and Zargham Borujeni (1393).

Eighth hypothesis: The "executor inclination" factor is related to the implementation of general lines.

According to the results presented in Table 4, the mean of the relationship between the "executor inclination" and the implementation of the policies of the Office of Natural Resources and Watershed of Khorasan Razavi province was 4.67 with a standard deviation of 0.4 and a median of 4.667. Also, the level of significance of the test was 0.0001 ; therefore, the null hypothesis is rejected.

The final model of the management of natural resources and watershed management in Khorasan Razavi province and 28 subsidiary offices in 28 provinces of the province is verified as the following figure and the researcher called it " $8 \mathrm{t}$ Model".

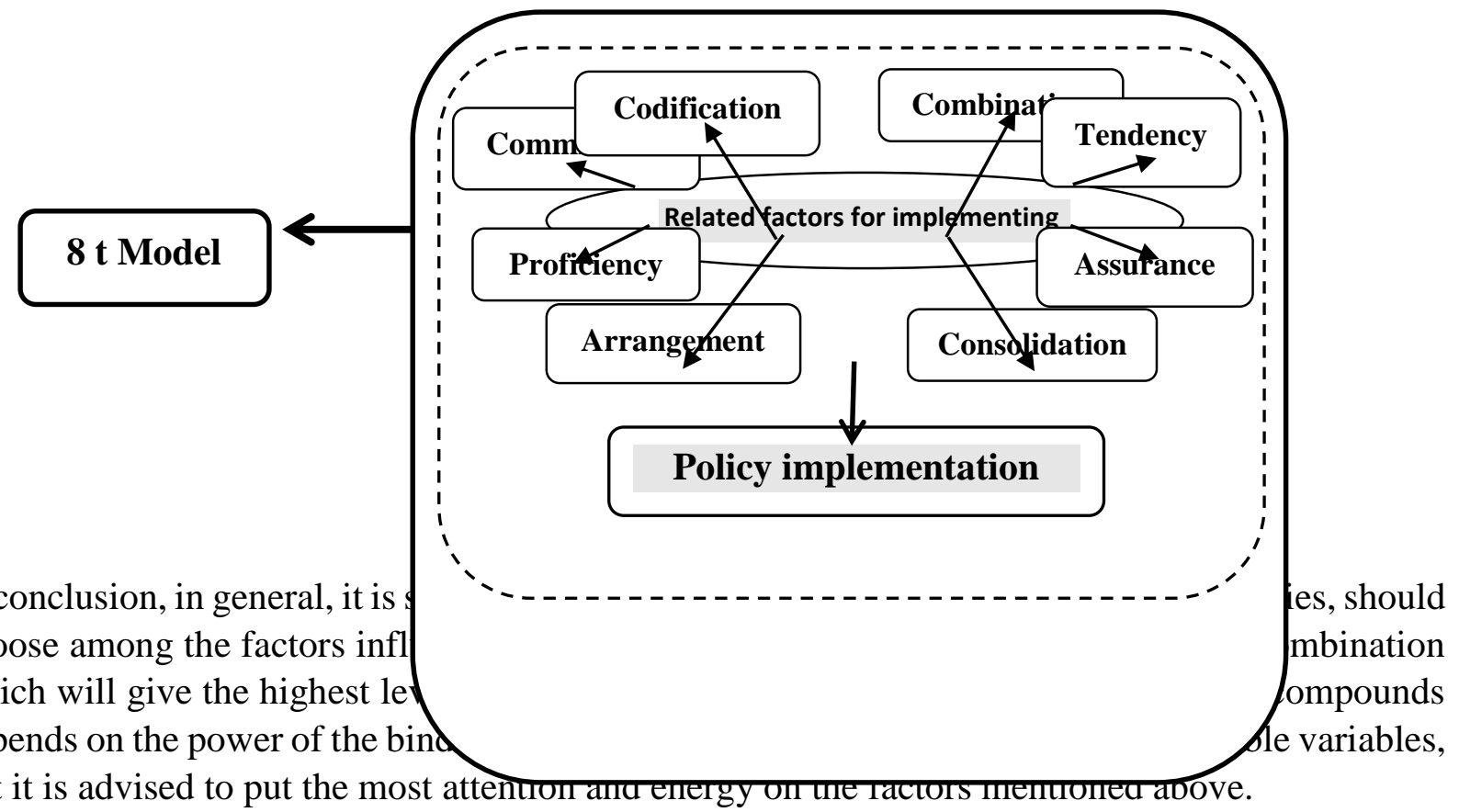

Also, it is recommended that executive administrators of the Regional Directorate for Natural Resources and Watershed of Khorasan Razavi province should be informed about the objectives of the vision document, the strategies and policies, the targeted training courses, and continuous evaluation of the feedback of this course so that all employees involved in the implementation of 
the policies will use them. When the information and awareness of the executives is sufficient from the philosophy of doing their work, the quality of the performance will be better and higher.

Table 1. Summary of studies on general policy

\begin{tabular}{|c|c|c|c|}
\hline $\mathbf{N}$ & Author & Year & Field and perspectives \\
\hline 1 & $\begin{array}{l}\text { Persman and } \\
\text { Wildovsky }\end{array}$ & 1973 & $\begin{array}{l}\text { Warnings and command terms to accept policy } \\
\text { implementation: }\end{array}$ \\
\hline 2 & $\begin{array}{l}\text { Van horn } \\
\text { and van } \\
\text { miter }\end{array}$ & 1975 & $\begin{array}{l}\text { Implementation should not be separated from the policy, } \\
\text { direct instruments used in the implementation, taking into } \\
\text { account the scientific and theoretical foundations, continuity } \\
\text { of leadership, simplicity and policy simplification }\end{array}$ \\
\hline 3 & $\begin{array}{l}\text { Melbourne } \\
\text { McLogin }\end{array}$ & 1975 & Runtime variables: \\
\hline 4 & $\begin{array}{l}\text { Rin and } \\
\text { Robin Witz }\end{array}$ & 1978 & $\begin{array}{l}\text { Standards and Objectives, Resources, Organizational } \\
\text { Relationships, Characteristics of Executive Agencies, } \\
\text { Personality Characteristics of Applicants, Economic, Political, } \\
\text { and Social Conditions }\end{array}$ \\
\hline 5 & $\begin{array}{l}\text { Richard } \\
\text { Elmore }\end{array}$ & 1980 & Key factors in success or failure: \\
\hline 6 & $\begin{array}{l}\text { Garcia } \\
\text { Zamor }\end{array}$ & 1980 & $\begin{array}{l}\text { Political elites, voters, interest groups, political parties, } \\
\text { personal relationships between policy makers and policy } \\
\text { makers, the extent to which administrators accept the policy } \\
\text { change and the level of interest, commitment and support of } \\
\text { policy key actors. }\end{array}$ \\
\hline 7 & $\begin{array}{l}\text { James } \\
\text { Anderson }\end{array}$ & 1982 & $\begin{array}{l}\text { Major causes of poor policy implementation: } \\
\text { Lack of knowledge and understanding of the orders by the } \\
\text { executives, the impossibility of implementing the decision, } \\
\text { the resistance of the executives in the implementation of the } \\
\text { policy }\end{array}$ \\
\hline 8 & $\begin{array}{l}\text { Gan and } \\
\text { Hagwood }\end{array}$ & 1984 & $\begin{array}{l}\text { Conditions that cause the policy to fail correctly: } \\
\text { Out-of-office and non-operating factors, inadequate time and } \\
\text { inaccessibility of appropriate and appropriate resources, lack } \\
\text { of valid theory of cause and effect, lack of direct } \\
\text { communication between causes and disadvantages, excessive } \\
\text { communication between executive units, lack of } \\
\text { understanding and lack of agreement Objectives, lack of } \\
\text { clarity of tasks and lack of coordination, lack of requests from } \\
\text { authorities and authorities to complete policy implementation }\end{array}$ \\
\hline 9 & Winter & 1990 & $\begin{array}{l}\text { By summing up the views of some experts, it presents a } \\
\text { model that names four categories of variables that affect } \\
\text { policy implementation: variables related to the policy } \\
\text { formulation process, variables related to organizational and } \\
\text { inter-organizational execution, variables related to The } \\
\text { behavior of street level bureaucrats (those who are responsible }\end{array}$ \\
\hline
\end{tabular}




\begin{tabular}{|c|c|c|c|}
\hline & & & $\begin{array}{l}\text { for delivering government services to the target group are } \\
\text { under the law, such as tax auditors) and variables related to } \\
\text { the target group's response and community change }\end{array}$ \\
\hline 10 & Castillo & 1995 & $\begin{array}{l}\text { A. Obstacles: } \\
\text { Inadequate resources, inappropriate means, deviations from } \\
\text { political intentions (political strife), inadequate early plans, } \\
\text { non-obligatory commitment of policy makers. } \\
\text { B) The factors or variables that affect the implementation: } \\
\text { Internal factors include the power settings or the combined } \\
\text { powers of networks and venues, external factors including } \\
\text { public opinion, interpretative institutions, and individuals }\end{array}$ \\
\hline 11 & $\begin{array}{l}\text { Sabatyr and } \\
\text { Mazmanian }\end{array}$ & 1996 & $\begin{array}{l}\text { Policy effective policy conditions: } \\
\text { Clear goals, causal relationships and having theoretical basis, } \\
\text { a stabilizing player and a leader with political and managerial } \\
\text { skills, policy support by lawmakers, executive authorities, } \\
\text { judicial authorities and target groups, attention to social } \\
\text { conditions , Economic and international }\end{array}$ \\
\hline 12 & $\begin{array}{l}\text { Howellt and } \\
\text { Ramesh }\end{array}$ & 1995 & $\begin{array}{l}\text { A) Policy enforcement constraints: } \\
\text { The limitations related to the nature of the problem include: } \\
\text { technical difficulties, multiplicity of goals, group size, and } \\
\text { behavioral changes caused by policy in the target group. The } \\
\text { conditions governing the society include the political, } \\
\text { economic, social and emergence of new technologies, } \\
\text { constraints and problems associated with the organizer and } \\
\text { policy implementers. } \\
\text { B) The criteria for designing and implementing the policy: } \\
\text { Policymakers should state their policy and hierarchy goals as } \\
\text { clearly as possible and in clear instructions. Policy-making } \\
\text { should be explicitly or implicitly based on a credible source } \\
\text { theory and contain clear provisions to be implemented } \\
\text { correctly by the executing organization. The task of the } \\
\text { implementation should be given to organizations with } \\
\text { sufficient experience and commitment. }\end{array}$ \\
\hline 13 & $\begin{array}{l}\text { Eugene } \\
\text { Bardaha }\end{array}$ & 1977 & $\begin{array}{l}\text { A) Ways to get groups and actors involved in policy } \\
\text { implementation include: stimulating, bargaining, bargaining, } \\
\text { persuading, and persuading } \\
\text { B) Some of the techniques and games provided by the policy } \\
\text { makers to prevent the correct implementation are: } \\
\text { Budget play, peace keeping, collective resistance, easy and } \\
\text { comfortable life and other games } \\
\text { C) The negative effects of the policy can be noted as follows: } \\
\text { Change profits, deviation from policy goals, resistance to } \\
\text { administrative controls }\end{array}$ \\
\hline 14 & Edwards & 1980 & $\begin{array}{l}\text { Important factors affecting the implementation of policies: } \\
\text { Communications, resources, tendencies, attitudes and } \\
\text { bureaucratic structure }\end{array}$ \\
\hline
\end{tabular}




\begin{tabular}{|c|c|c|c|}
\hline 15 & $\begin{array}{l}\text { Nakamura } \\
\text { and } \\
\text { Smallville }\end{array}$ & 1980 & $\begin{array}{l}\text { In describing three policy environments (formulation, } \\
\text { implementation and policy assessment), they list three } \\
\text { variables: actors and domains, organizational structures and } \\
\text { bureaucratic norms and communication networks, and the } \\
\text { mechanism of compliance and acceptance. }\end{array}$ \\
\hline 16 & Falan & 1982 & $\begin{array}{l}\text { Objectives are not clear, the goals are scattered, the } \\
\text { indeterminacy of the implementation tools }\end{array}$ \\
\hline 17 & $\begin{array}{l}\text { Hey Yong } \\
\text { Sook }\end{array}$ & 1988 & $\begin{array}{l}\text { In his study, he lists four factors influencing policy } \\
\text { implementation: policy agents (including policy type, } \\
\text { resources, incentives, degree of change and complexity, } \\
\text { compatibility and legitimacy, clarity and clarity), intervention } \\
\text { factors (including communication and coordination, Time, } \\
\text { implementation strategies, staff training, acceptance process, } \\
\text { clear and continuous correlation and elimination of fear and } \\
\text { uncertainty), environmental factors (including social, } \\
\text { economic and political support, organizational structure, } \\
\text { organizational climate and other support) and the factors of } \\
\text { the executive (Employee perceptions, employee competence } \\
\text { and willingness) }\end{array}$ \\
\hline 18 & Berry et al & 1988 & $\begin{array}{l}\text { The determinants of policy implementation: communication } \\
\text { factors, condition factors, ability and ability factors }\end{array}$ \\
\hline 19 & $\begin{array}{l}\text { Papados } \\
\text { Paul }\end{array}$ & 1988 & $\begin{array}{l}\text { The incorrectness of the policy theory and the lack of a valid } \\
\text { causal theory, the existence of long chain causation and } \\
\text { hierarchy of cause and effect, the lack of sufficient time and } \\
\text { resources, the lack of an adequate mix of resources for access, } \\
\text { external crippling constraints, a lack of major review in Rules }\end{array}$ \\
\hline 20 & $\begin{array}{l}\text { Alance and } \\
\text { Worcester }\end{array}$ & 1973 & $\begin{array}{l}\text { Effective Factors on Failure: Inappropriate distribution of } \\
\text { power that leads to weak analyzes of issues, domination of } \\
\text { specific interests on policy, the lack of an appropriate and } \\
\text { comprehensive strategy for promoting public interest, failing } \\
\text { to understand key issues, revising and overlapping the actions } \\
\text { of various organizations, conflict The missions and plans of } \\
\text { the organization are to sharpen the inter-institutional } \\
\text { committees to create synergies. }\end{array}$ \\
\hline 21 & $\begin{array}{l}\text { Palmbo and } \\
\text { Callista }\end{array}$ & 1990 & $\begin{array}{l}\text { Factors affecting performance failures: Symbolic policies, } \\
\text { lack of theoretical basis, rapid social, economic, political } \\
\text { changes and lack of necessary dynamics in the state, } \\
\text { inadequate resources, lack of necessary tools for } \\
\text { administrators to use inappropriate organizational programs } \\
\text { and structures }\end{array}$ \\
\hline 22 & Ago Novan & 1991 & $\begin{array}{l}\text { Effective Factors on Failure of Implementation: Definition of } \\
\text { inadequate goals (lack of transparency, internal coherence and } \\
\text { compatibility with other political goals), ambitious policy } \\
\text { objectives, selection of inappropriate organizational structure } \\
\text { in implementation, discretion of programs }\end{array}$ \\
\hline
\end{tabular}




\begin{tabular}{|c|c|c|c|}
\hline 23 & Warwick & 1982 & $\begin{array}{l}\text { Successful implementation: Continuous adaptation to fields, } \\
\text { characters, events through the desire to acknowledge and } \\
\text { correct mistakes. }\end{array}$ \\
\hline 24 & Hawlt & & $\begin{array}{l}\text { Factors Affecting Run Failure: } \\
\text { A. Internal factors: a large number of policies, technical } \\
\text { difficulties, wide and diverse target groups, } \\
\text { (B) External factors: changes in the social situation, political } \\
\text { changes, the way organizers organize, the resources of } \\
\text { political and economic groups, their support and support, lack } \\
\text { of public support }\end{array}$ \\
\hline 25 & Denhart & & $\begin{array}{l}\text { Factors of failure: a large number of contributors to the } \\
\text { implementation, the existence of different perspectives, a long } \\
\text { way to practical action, multiple departments involved and } \\
\text { decision making in the implementation and competitor } \\
\text { resources }\end{array}$ \\
\hline 26 & Quing & 1986 & $\begin{array}{l}\text { Failure factors: ambiguous targeting, cognitive limitations of } \\
\text { policy makers and the unpredictable environment. }\end{array}$ \\
\hline 27 & $\begin{array}{l}\text { Alish and } \\
\text { Petak }\end{array}$ & 1986 & $\begin{array}{l}\text { Factors Affecting Run Failure: Failure to pay attention to } \\
\text { unexpected side effects and their inconsistency, lack of } \\
\text { attention to the desired effects in target groups }\end{array}$ \\
\hline 28 & Brinker Huff & 1996 & $\begin{array}{l}\text { Policy defeat: Inconsistency and incompatibility of the } \\
\text { internal elements of the policy }\end{array}$ \\
\hline 29 & $\begin{array}{l}\text { Morten } \\
\text { Egger }\end{array}$ & 1999 & $\begin{array}{l}\text { Factors affecting failure of the operation: the lack of clarity of } \\
\text { the duties and responsibilities of the operating system, the } \\
\text { lack of sufficient communication between the operating } \\
\text { systems }\end{array}$ \\
\hline 30 & Grindel & 2000 & $\begin{array}{l}\text { Basic Policy Implementation Principles: The overall } \\
\text { implementation process begins when the goals and objectives } \\
\text { are specifically expressed, the operational plans are designed, } \\
\text { and the capital is assigned to pursue the objectives. }\end{array}$ \\
\hline 31 & Hafiz Khalid & 2001 & $\begin{array}{l}\text { Factors Affecting Failure of Implementation: lack of } \\
\text { creativity and necessary innovations in executives to } \\
\text { implement policies, neglecting the interests of interest groups, } \\
\text { lack of citizen support, government employment to overcome } \\
\text { political concerns, non-alignment of government executives }\end{array}$ \\
\hline 32 & $\begin{array}{l}\text { American } \\
\text { Government } \\
\text { Management } \\
\text { Association }\end{array}$ & 2002 & $\begin{array}{l}\text { Barriers to Effective Implementation: } \\
\text { (A) Institutional barriers: Infrastructure costs, lack of } \\
\text { incentives for innovation, lack of policy guidance } \\
\text { B) Management barriers: lack of managerial capabilities, } \\
\text { weak management of information, duplicity and resistance } \\
\text { from the political leader, opposition from professional } \\
\text { stakeholders, negative attitude of senior and middle managers }\end{array}$ \\
\hline 33 & Khoza & 2003 & $\begin{array}{l}\text { Failure factors in implementation: Unrealistic policies, lack of } \\
\text { management expertise, lack of process guiding people, } \\
\text { inadequate coordination of policy implementation. }\end{array}$ \\
\hline
\end{tabular}




\begin{tabular}{|c|c|c|c|}
\hline 34 & Squat & 2004 & $\begin{array}{l}\text { Failure to monitor the effectiveness of policies, prevent policy } \\
\text { makers from engaging with policy makers in analyzes and } \\
\text { development steps, failing to integrate social and economic } \\
\text { analyzes, and not determine how policies affect the various } \\
\text { stakeholders. }\end{array}$ \\
\hline 35 & Makinde & 2005 & $\begin{array}{l}\text { Failure factors in implementation: Inadequate communication } \\
\text { and information, lack of adequate resources and facilities, } \\
\text { incentives and attitudes of executives, evaluators of policy } \\
\text { implementation (conflict between implementation and their } \\
\text { interests), policy emanation from the government instead of } \\
\text { Target groups without paying attention to social, political, } \\
\text { economic and administrative variables, lack of directors' } \\
\text { control of the supportive environment necessary for decision } \\
\text { making, inadequate executive pay and salary, lack of } \\
\text { expertise in administrators, ambiguous policies, large number } \\
\text { of policies, Centralized decision making, lack of coordination } \\
\text { mechanism, lack of control over received information, non- } \\
\text { alignment of government implementation plans, Disregard for } \\
\text { interest groups, lack of citizen support, recruitment to resolve } \\
\text { political concerns, the multiplicity and interference of the } \\
\text { authorities of policy makers, inconsistency of policy makers' } \\
\text { objectives, deferral of implementation, slowness of the } \\
\text { process of reforming policies in executive agencies }\end{array}$ \\
\hline 36 & Brinard & 2005 & $\begin{array}{l}\text { Failure factors in the implementation: the failure of the } \\
\text { managers to the policies developed by the experts, the lack of } \\
\text { commitment in the implementation, the implementation of } \\
\text { individual opinions of executives and executives, the conflict } \\
\text { between the interests of the executives and the } \\
\text { implementation, lack of expertise, lack of agreement with the } \\
\text { policies, Unrealistic policies, lack of coordination } \\
\text { mechanisms, inadequate communication of host devices, } \\
\text { unnoticed to beneficiary groups, lack of citizen support, } \\
\text { employment of political concerns, multiple and conflicting } \\
\text { powers of policy makers, inconsistency of policy makers, } \\
\text { postponement In execution, the slow process of correction of } \\
\text { policies in the operating systems }\end{array}$ \\
\hline 37 & $\begin{array}{l}\text { Lee, Laie } \\
\text { and Fingers }\end{array}$ & 2006 & $\begin{array}{l}\text { Barriers to successful implementation of policies: lack of } \\
\text { transparency in implementation evaluation criteria, lack of } \\
\text { relevant program planners, divergence of viewpoints of } \\
\text { planners and executives, differing priorities of the plan with } \\
\text { the priorities of the private sector }\end{array}$ \\
\hline 38 & John Cohen & 2006 & $\begin{array}{l}\text { Constraints of the barrier to successful implementation: } \\
\text { political and economic constraints, especially economic ones } \\
\text { such as budget balance, external balance constraint, constrain } \\
\text { deficit, replacement effect, limitation of globalization }\end{array}$ \\
\hline
\end{tabular}




\begin{tabular}{|c|c|c|c|}
\hline 39 & $\begin{array}{l}\text { Samuel } \\
\text { Stalli }\end{array}$ & 2006 & $\begin{array}{l}\text { Factors affecting performance failure: Relying on the role of } \\
\text { the market and economic mechanisms, overcoming the } \\
\text { political dimensions of the economy and the dominance of } \\
\text { official officials on market forces, lack of coordination, } \\
\text { political concern with policy objectives, regulatory and } \\
\text { regulatory process in policy making, lack of clear codification } \\
\text { Objectives, unavailability of the necessary administrative } \\
\text { mechanisms, lack of political support, inability to process } \\
\text { information, limitations of knowledge of administrators }\end{array}$ \\
\hline 40 & $\begin{array}{l}\text { Su Zhang } \\
\text { and Roney }\end{array}$ & 2006 & $\begin{array}{l}\text { Effective Factors on Performance Failure: Clear and unclear } \\
\text { policy goals, lack of dynamism of policies, without notice of } \\
\text { existing operational capacities }\end{array}$ \\
\hline 41 & Burgunde & 2007 & $\begin{array}{l}\text { Effective Factor on Failure of Implementation: Competition } \\
\text { and Long-standing Conflict Between Entrepreneur } \\
\text { Organizations }\end{array}$ \\
\hline 42 & $\begin{array}{l}\text { Papeete } \\
\text { Dalívida }\end{array}$ & 2008 & $\begin{array}{l}\text { Factors affecting implementation failure: lack of political } \\
\text { support, limited financial resources, constraints on } \\
\text { institutional capacity, poor cooperation at local level }\end{array}$ \\
\hline 43 & $\begin{array}{l}\text { Mortazavi, } \\
\text { Foruzand } \\
\text { and others }\end{array}$ & 2011 & $\begin{array}{l}\text { The Factors and Barriers to the Implementation of the Law of } \\
\text { the State Service Management: } \\
\text { The form and content of the law, supervision } \\
\text { Tools and prerequisites, law enforcers }\end{array}$ \\
\hline 44 & $\begin{array}{l}\text { Qalipur, } \\
\text { Wanayfard } \\
\text { and others }\end{array}$ & 2011 & $\begin{array}{l}\text { Effective Factors in Implementation: Implementation Culture, } \\
\text { Implementation Capacity, Implementation Entrepreneurship, } \\
\text { Collaboration in Implementation and, ultimately, Effective } \\
\text { Implementation of Industrial Policies }\end{array}$ \\
\hline 45 & $\begin{array}{l}\text { Moghads } \\
\text { pour, Danayi } \\
\text { fard, } \\
\text { Kurdnaiij }\end{array}$ & 2012 & $\begin{array}{l}\text { Key factors hampering the implementation of public policy in } \\
\text { Iran: neglecting the value of time and opportunities in } \\
\text { implementing national policies, management instability in the } \\
\text { public sector, implementing policies, inconsistencies in the } \\
\text { implementation of national policies, internal crises And } \\
\text { external influences on the implementation of policies, the lack } \\
\text { of an appropriate executive structure for the implementation } \\
\text { of national policies }\end{array}$ \\
\hline 46 & $\begin{array}{l}\text { Porkani, } \\
\text { Sallajhet and } \\
\text { others }\end{array}$ & 2014 & $\begin{array}{l}\text { Obstacles to the implementation of government policies: } \\
\text { Barriers to logic, coherence and realism, structure and } \\
\text { resources, the legal environment, concept and writing, review } \\
\text { and oversight, staff and managers, and theoretical support }\end{array}$ \\
\hline 47 & $\begin{array}{l}\text { Zargham } \\
\text { Boroujeni }\end{array}$ & 2014 & $\begin{array}{l}\text { Factors influencing the implementation of policies: Attention } \\
\text { to the behavioral and personality characteristics of the } \\
\text { executives, } 2 \text {. The administrative system and bureaucracy, } 3 \text {. } \\
\text { Purposeful and proper policy making, 4. Executive expertise } \\
\text { and skill, 5. Target groups and users, } 6 \text {. Support By legal, } \\
\text { legal, 7. Select appropriate tools and resources for policy } \\
\text { implementation. }\end{array}$ \\
\hline
\end{tabular}




\begin{tabular}{|c|c|c|c|}
\hline 48 & $\begin{array}{l}\text { Khannifer, } \\
\text { Alvani and } \\
\text { others }\end{array}$ & 2015 & $\begin{array}{l}\text { Then, the stakeholder network (including people, } \\
\text { organizations, devices, and institutions), the implementation } \\
\text { dimension of the research (including resource mobilization, } \\
\text { tools and implementation approaches), the community's } \\
\text { mental and value space }\end{array}$ \\
\hline 49 & $\begin{array}{l}\text { Hajjpour, } \\
\text { Foruzand } \\
\text { and others }\end{array}$ & 2015 & $\begin{array}{l}\text { General public policy (political, economic and technological } \\
\text { conditions, social and cultural, international), general public } \\
\text { policy area (layout makers, linearization process, linear } \\
\text { structure Exercise space, general policy execution } \\
\text { environment (line administrators, organizer structures, } \\
\text { resources and capacities, evaluation and monitoring). } \\
\text { Outcomes (line failure, public trust distraction, policy maker } \\
\text { and executor damage) }\end{array}$ \\
\hline 50 & $\begin{array}{l}\text { Abbasi, } \\
\text { Motazidian } \\
\text { and others }\end{array}$ & 2016 & $\begin{array}{l}\text { Policy makers, implementers and users, the nature of the line, } \\
\text { the organizer, the types of actions and pressure groups, the } \\
\text { context of the implementation of the line }\end{array}$ \\
\hline
\end{tabular}

Table 2. Cronbach's alpha coefficients for the research variables in the final sample

\begin{tabular}{lll}
\hline $\mathbf{N}$ & \multicolumn{1}{c}{ Items } & $\begin{array}{c}\text { Alpha } \\
\text { coefficient }\end{array}$ \\
\hline & $\begin{array}{l}\text { Executory } \\
\text { experience } \\
\text { and } \\
\text { commitment }\end{array}$ & 0.7091 \\
\hline 2 & Bureaucracy & 0.7597 \\
\hline 3 & $\begin{array}{l}\text { How to } \\
\text { formulate a } \\
\text { policy }\end{array}$ & 0.7618 \\
\hline 4 & $\begin{array}{l}\text { Target } \\
\text { community }\end{array}$ & 0.7326 \\
\hline 5 & tool & 0.7337 \\
\hline 6 & $\begin{array}{l}\text { implementatio } \\
\text { guarantee }\end{array}$ & 0.7843 \\
\hline 7 & $\begin{array}{l}\text { Executor } \\
\text { Specialty }\end{array}$ & 0.7193 \\
\hline 8 & $\begin{array}{l}\text { The } \\
\text { inclination of } \\
\text { the presenter }\end{array}$ & 0.7632 \\
\hline & \multicolumn{2}{c}{$\begin{array}{l}\text { the } \\
1\end{array}$} \\
\hline
\end{tabular}




\begin{tabular}{lll}
\hline - & $\begin{array}{l}\text { Total } \\
\text { questionnaire }\end{array}$ & 0.8840 \\
\hline
\end{tabular}

Table 3. Kolmogorov-Smirnov Test

\begin{tabular}{|c|c|c|c|c|c|c|}
\hline \multirow[t]{2}{*}{$\mathbf{Z}$} & \multirow{2}{*}{ Variables } & \multicolumn{2}{|c|}{$\begin{array}{l}\text { Descriptive } \\
\text { statistes }\end{array}$} & \multicolumn{2}{|c|}{$\begin{array}{l}\text { Kolmogorov- } \\
\text { Smirnov Test } \\
\end{array}$} & \multirow{2}{*}{ results } \\
\hline & & $\mathbf{M}$ & SD & $\mathbf{Z}$ & Sig & \\
\hline 1 & $\begin{array}{l}\text { Executory } \\
\text { experience and } \\
\text { commitment }\end{array}$ & 4.79 & 0.28 & 2.801 & 0.0001 & abnormal \\
\hline 2 & Bureaucracy & 4.5 & 0.29 & 2.044 & 0.0001 & abnormal \\
\hline 3 & $\begin{array}{l}\text { How to } \\
\text { formulate a } \\
\text { policy }\end{array}$ & 4.55 & 0.38 & 1.607 & 0.011 & abnormal \\
\hline 4 & $\begin{array}{l}\text { Target } \\
\text { community }\end{array}$ & 4.36 & 0.52 & 1.765 & 0.004 & abnorma \\
\hline 5 & tool & 4.7 & 0.45 & 3.667 & 0.0001 & abnormal \\
\hline 6 & $\begin{array}{l}\text { implementation } \\
\text { guarantee }\end{array}$ & 4.58 & 0.36 & 1.808 & 0.003 & abnorma \\
\hline 7 & $\begin{array}{l}\text { Executor } \\
\text { specialty }\end{array}$ & 4.59 & 0.32 & 1.471 & 0.026 & abnorma \\
\hline 8 & $\begin{array}{l}\text { Executor } \\
\text { inclination }\end{array}$ & 4.67 & 0.4 & 2.612 & 0.0001 & abnorma \\
\hline - & Total factors & 4.59 & 0.25 & 1.468 & 0.044 & abnormal \\
\hline
\end{tabular}

Table 4. The results of the single t-test of the relationship between the factors associated with the implementation of general policies

\begin{tabular}{lccccccc}
\hline \multicolumn{1}{c}{ Variables } & M & SD & Median & $\begin{array}{c}\text { Numbers } \\
\text { less than } \\
\text { median }\end{array}$ & $\begin{array}{c}\text { Numbers } \\
\text { equivalent } \\
\text { to median }\end{array}$ & $\begin{array}{c}\text { Numbers } \\
\text { more } \\
\text { than } \\
\text { median }\end{array}$ & Sig \\
\hline $\begin{array}{l}\text { Executor } \\
\text { experience }\end{array}$ & 4.79 & 0.28 & 5 & 0 & 0 & 92 & 0.0001 \\
\hline Bureaucracy & 4.5 & 0.29 & 4.5 & 0 & 0 & 92 & 0.0001 \\
\hline
\end{tabular}




\begin{tabular}{lccccccc}
\hline $\begin{array}{l}\text { How to } \\
\text { formulate a } \\
\text { policy }\end{array}$ & 4.55 & 0.38 & 4.529 & 0 & 0 & 92 & 0.0001 \\
\hline $\begin{array}{l}\text { Target } \\
\text { community }\end{array}$ & 4.36 & 0.52 & 4.25 & 0 & 3 & 89 & 0.0001 \\
\hline tool & 4.7 & 0.45 & 5 & 0 & 0 & 92 & 0.0001 \\
\hline $\begin{array}{l}\text { implementation } \\
\text { guarantee }\end{array}$ & 4.58 & 0.36 & 4.625 & 0 & 0 & 92 & 0.0001 \\
\hline $\begin{array}{l}\text { Executor } \\
\text { Specialty }\end{array}$ & 4.59 & 0.32 & 4.667 & 0 & 0 & 92 & 0.0001 \\
\hline $\begin{array}{l}\text { The inclination } \\
\text { of the executor }\end{array}$ & 4.67 & 0.4 & 4.667 & 0 & 1 & 91 & 0.0001 \\
\hline
\end{tabular}

\section{References}

1. Sharifizadeh, F, Bidgoli, AS (2008), Analysis of the Relationship between Organizational and Management Factors Using the Quantitative and Qualitative Development Plan of the Ph.D. Management Program, Improvement and Development Management Studies, No. 57, pp. 53 To 86

2. Hajipur, A., Foruzandeh, L.; Dananefard, H., Fani, A. (2016), Design of the pathology pattern of general policy implementation in Iran), Journal of military management research, no. 58 , pp. 1 Until 23

3. Kalyapur R. Knowing h Zareemitin h Jandegi Gh (2011), Presentation of a Model for Industrial Policies of Qom Province), Organizational Culture Management. Volume 9, Issue 3, Pages 103-130.

4. Sacred Scripture Knowing h (2014), Examining Key Elements in the Failure of Some Common Policies in Iran: Tax Policies of the Country, Journal of Management of Organizational Culture, Volume 11, Issue 1, Pages 33-68.

5. Alvani M. Sharifzadeh F (2011), Public Policies Process, Eighth Edition, Tehran: Allameh Tabatabaei University Press.

6. Danesh Hosseini Fani A., (2014), General Policy Capacity: The Key to National Development), First Edition, Tehran: Saffar Publishing.

7. Gholipour R, (2014), Organizational decision making and general policy making), Tehran: Publication of the position.

8. Alvani M. Amiri m Ahmadi K, (2012), From Organizational Social Ethics to Organizational Social Responsibility, An Approach for Establishing a Social Organizational Accountability System in Iranian Government Organizations, Journal of Ethics in Science and Technology, Vol. 7, No. 1, pp. 27-37. 
9. Banaian H., (2008), Information Systems Management Information System Development, Deputy Director General of Finance, Faculty of Finance, Department of Finance, University of the Persian Gulf), Payam Management Magazine No. 26, pp. 145-171.

10. Danayi fard. Lajevardi S., (2011), Improving Country Policy Capacity: Typology of the Role of Centers of Thinking. 9, Public Management, Volume 3, Issue 6, Pages 55-78.

11. David B. Truman. (1971). The governmental Process. 2d ed.New York: Alfred A. Knopf)

12. Howlett, M, Ramesh, M. \& Perl, A. 2009. Studying Public Policy: Policy Cycles \& Policy Subsystems, Oxford: Oxford University Press.

13. Lawrence BM. (1988). Impact Analysis for Program Evaluation .Pacific Grove, CA: Brooks. p.23.

14. Lind blom, C. (1984). Policy Making Process. N.J.: Prentice Hall, Inc.

15. Linder, s. \& Peters, G. (1989). Instruments of Government. Journal of Public Policy, 10. p. 1.

16. Mintz, A., \& DeRouen, k. 2010. Understanding Foreign Policy Decision Making: Cambridge University Press. pp. 141-172.

17. Palumbo, Dennis. 1981. The State of Policy Studies Research AND The Policy of the New Policy Studies Review. Policy Studies Review 1. pp. 5-10.

18. Paul Berman. 1986. The Study of Macro and micro Implementation, Public policy. vol. 26. No. 2. p. 138.

19. Pressman, J.A. W. Aaron, Ed. 1973. Implementation .Berkeley University of California Press.

20. Quintus, J.R, George, J.M. 2005. Emergent Strategies and Their Consequences: A Process Study of Competition and Complex Decision Making, in Gabriel Szulanski, Joe Porac, Yves Doz . Strategy Process (Advances in Strategic Management). Vol 22. Pp.387-411.

21. Wildman, J.L. Salas. E. 2009. Making it practical: simulation, naturalistic decision making and complexity in team performance, in Francis J. Yammarino, Fred Dansereau. Multi Level Issues in Organizational Behavior and Leadership. Research in MultiLevel Issues, Vol 8. Emerald Group Publishing Limited. 